Journal of Agriculture and Natural Resources (2018) 1(1): 21-31

ISSN: 2661-6270 (Print), ISSN: 2661-6289 (Online)

\title{
Research Article \\ Economics of fish production at Chitwan district, Nepal
}

${ }^{1}$ Tara Sharma, ${ }^{2}$ Shiva Chandra Dhakal, ${ }^{2}$ Rishi Ram Kattel, ${ }^{2}$ Kamala Gharti and

${ }^{3}$ Jeevan Lamichhane

${ }^{1}$ Department of Agriculture, Kathmandu, Nepal

${ }^{2}$ Agriculture and Forestry University, Rampur, Chitwan, Nepal

${ }^{3}$ Nepal Agricultural Research Council

*Correspondence: sharmatara236@ gmail.com; ORCID: https://orcid.org/0000-0001-5783-8937

Received: July 26; Accepted: December 01; Published: December 09.

(C) Copyright: Sharma et al. (2018).

This work is licensed under a Creative Commons Attribution-NonCommercial 4.0 International License.

\begin{abstract}
A study was conducted in 2016 to analyze the economics of fish production at Chitwan District of Nepal. Three study sites: East, West and South part of Chitwan were selected purposively. A total of 90 households, 30 from each study site were selected randomly and were interviewed by using pre-tested semi structured questionnaire. Secondary data needed for the study were obtained from DADO, MOAD, NARC and other related organizations working on fisheries and aquaculture sector. Descriptive statistics and extended Cobb Douglas production function was used to accomplish the study objectives for which MS-Excel and SPSS 16 were used. The B/C ratio is obtained dividing the gross return by total variable cost incurred. The total cost of production per ha of the pond area was Rs. 743798 per year with 79 and 21 percent variable and fixed cost components, respectively. Feed cost $(28 \%)$ was largest cost item followed by cost for labour (25\%), fingerlings (10\%), maintenance (6\%), manure cum fertilizers (5\%), fuel cum energy (3\%) and limestone and others ( $2 \%)$. The average gross return and net profit realized per ha were Rs. 1223934 and Rs. 480135 respectively. The cost, return and profit were calculated to be highest for east Chitwan with highest $\mathrm{B} / \mathrm{C}$ ratio followed by west Chitwan and south Chitwan. The B/C ratio for the district was found to be 1.63 . The return to scale was found to be decreasing with value of 0.654 indicating that 1 percent increment in all the inputs included in the function will increase income by 0.654 percent. Production function analysis, including five variables, showed significant effect of human labour, fingerlings and fuel cum energy cost but feed and manure cum fertilizers cost were insignificant.
\end{abstract}

Keywords: Fish, Cost, Return, Benefit Cost ratio, Production function

Correct citation: Sharma T., Dhakal, S.C., Kattel, R.R., Gharti, K., \& Lamichhane, J. L. (2018). Economics of fish production at Chitwan district, Nepal. Journal of Agriculture and Natural Resources, 1(1), 21-31. 
Journal of Agriculture and Natural Resources (2018) 1(1): 21-31

ISSN: 2661-6270 (Print), ISSN: 2661-6289 (Online)

\section{INTRODUCTION}

Nepal has rich fresh water resources including snow fed rivers, lakes, ponds and torrential hills stream. It is blessed with three major river systems - Koshi, Gandaki and Karnali. This vast water resource has been supporting several indigenous fish species which play a great role in income generating activities of landless and marginal farmers (DoFD, 2013). Fisheries have been practiced in Nepal since a long time and have a strong tradition in Nepal. Although it is not a main agricultural activity, is an important supplement to the daily diet in rural areas of Nepal contributing about 2.47 to AGDP (Rai, Clausen, \& Smith, 2008).

Fish farming in Chitwan has started since 2037/38 BS (DADO Chitwan,2072). Nearly 1255 farmers from 58 farmers group or cooperatives of this district were involved in fish farming. The total numbers of fish ponds were about 2073 with total area of more than 854 ha and water area of 539 ha. The annual fish production in the district was more than $264 \mathrm{mt}$ with productivity of $4.2 \mathrm{mt}$ per ha (Karki, 2016). The fish mission program has being implemented in the district since 2064/65 B.S.. Major fish breeds being cultivated in the district are Silver carp, Big head carp, Rohu, Naini, Common carp, Grass carp, Bhakur, Pangas etc. Along with local market, currently, fish produced in the district is being marketed to Kathmandu, Pokhara, Dhanusha, Siraha districts of the country (DADO Chitwan, 2072).

In Chitwan district, lots of farmer groups and cooperatives are involved in production and marketing of fish. It ranks second position among the ten highest fish producing districts of the country (Karki, 2016). The demand for fresh fish is increasing day by day due to increased consciousness of people towards their health and nutrition. Meeting the fish demand through capture fisheries and importing may not be sustainable; therefore promotion and management of pond aquaculture could be the only one alternative for the sustainability of this enterprise in Nepal. Findings from this study will guide producers and marketing institutions for efficient utilization of resources with proper production plan.

The objectives of the study were to analyze the economics of fish production at Chitwan District of Nepal, estimate the cost and return of fish production in study area, and analyze the profitability. Return to scale was calculated for assessing the elasticity of production for which Cobb Douglas production function was used.

\section{METHODOLOGY}

The study was conducted in Chitwan district. Three potential sites of Chitwan namely Ratnanagar and Khairahani municipalities from east Chitwan, Chitrawan municipality from west Chitwan and Madi municipality from south Chitwan, were selected purposively based on the fish production potentiality in consultation with stakeholders involved in fish production and marketing. 
Journal of Agriculture and Natural Resources (2018) 1(1): 21-31

ISSN: 2661-6270 (Print), ISSN: 2661-6289 (Online)

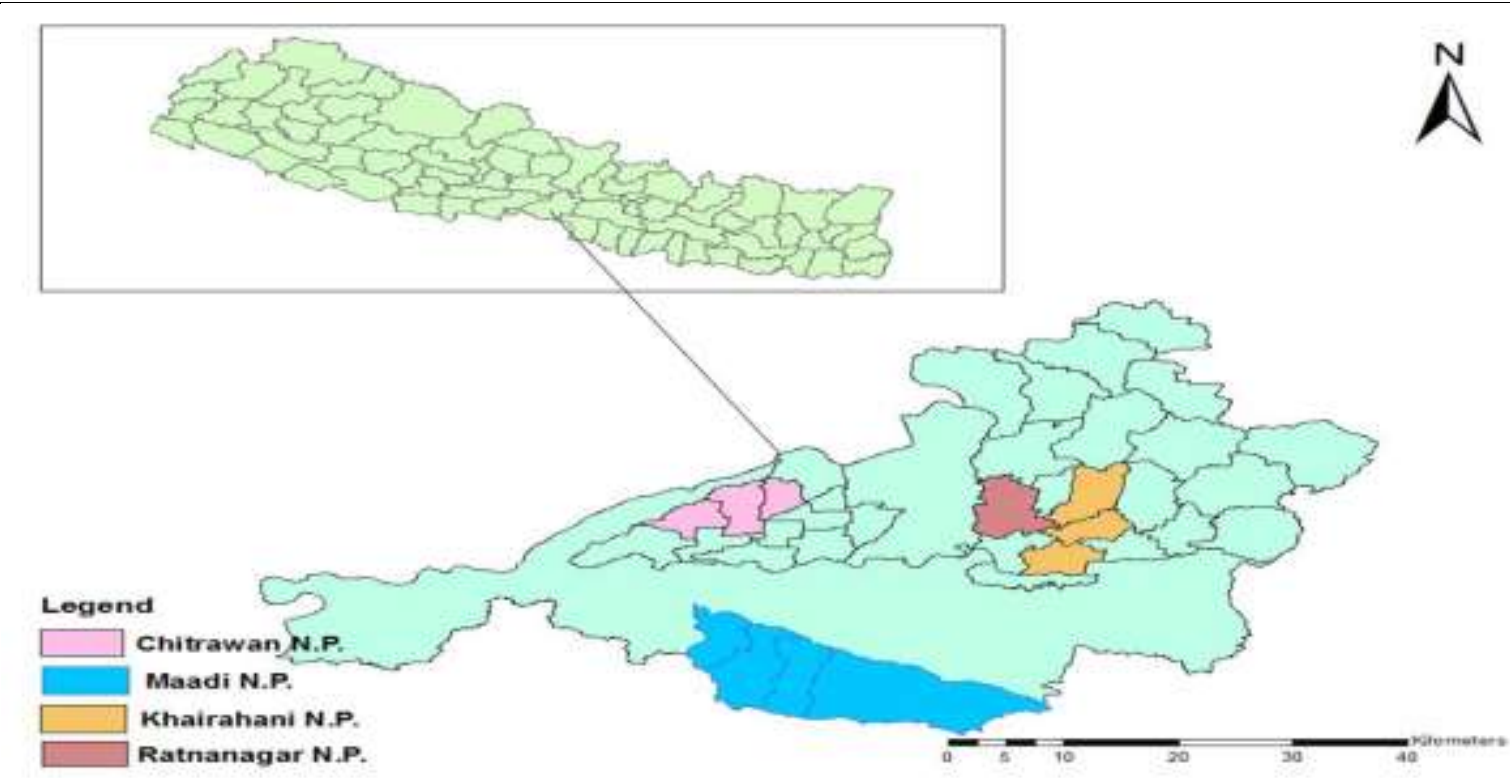

Fig 1: Map of the study area

A total of 90 households, 30 from each site were selected randomly and were interviewed by using pre-tested semi structured questionnaire. Secondary data needed for the study were obtained from DADO, MOAD, NARC and other related organizations working on fisheries and aquaculture sector. The information collected from survey was coded, tabulated and analyzed using SPSS 16 and MS excel (2007).

The total cost of production was calculated by summing total variable cost (TVC) and total fixed cost (TFC) incurred in the production process. The cost incurred for fingerlings, feed, energy cum fuel, manure cum fertilizers, labour (including hired and family labour), maintenance cost, lime and other cost were considered as variable cost. Whereas the expenses on land rent, interest payment and depreciation of farm tools and machineries were included under fixed cost.

The benefit cost ratio ( $\mathrm{B} / \mathrm{C}$ ratio) was calculated by dividing gross return with gross cost i.e. $\mathrm{B} / \mathrm{C}$ ratio $=$ Gross return/Total variable cost.

Gross return $($ Rs. $)=$ Total quantity of fish produced $(\mathrm{kg}) \times$ per $\mathrm{kg}$ price $(\mathrm{Rs}$.

TVC (Rs.) = Summation of cost incurred in all variable inputs.

Similarly, Net profit was calculated by deducting total cost (TC) of production from gross return i.e. Net profit (Rs.) = Gross return (Rs.) - Total cost (Rs.)

Where, TC (Rs.) = TVC (Rs.) + TFC (Rs.) 
Journal of Agriculture and Natural Resources (2018) 1(1): 21-31

ISSN: 2661-6270 (Print), ISSN: 2661-6289 (Online)

The return to scale was calculated from the Cobb Douglas production function as:

$y=A x_{1}^{\beta 1} x_{2}{ }^{\beta 2} x_{3}{ }^{\beta 3} x_{4}{ }^{\beta 4} x_{5}{ }^{\beta 5}$

On taking log on both sides;

In $y=\operatorname{In} A+\beta_{1} \ln x_{1}+\beta_{2} \ln x_{2}+\beta_{3} \ln x_{3}+\beta_{4} \ln x_{4}+\beta_{5} \ln x_{5}$

Where,

$\mathrm{Y}=$ Gross/Total return (Rs. /ha),

$A=$ Constant or Intercept of the function,

$\mathrm{X}_{1}=$ Labour cost (Rs. /ha),

$\mathrm{X}_{2}=$ feed cost (Rs. /ha),

$\mathrm{X}_{3}=$ Fingerlings cost (Rs./ha),

$\mathrm{X}_{4}=$ Fertilizers and manure cost (Rs./ha),

$\mathrm{X}_{5}=$ fuel and energy cost (Rs./ha),

$\beta_{1} \beta_{2} \ldots . . . \beta_{5}=$ Coefficient of respective variables,

ln = Natural logarithm

The summation of the all production coefficients indicates return to scale. Returns to scale reflects the degree to which a percent change in all inputs caused change in the output.

\section{RESULTS}

\section{Socio-demographic characteristics of the respondents}

The socio demographic characteristics of the respondents include population and gender distribution, ethnicity, family size, economically active population, education, occupation, land holding size, experience on fish farming.

Table 1. Socio-demographic characteristics of respondents in the study area

\begin{tabular}{ll}
\hline Socio-demographic characteristics & Mean value \\
\hline Age & 41 \\
Gender & 54 \\
$\quad$ i)Male(\%) & 46 \\
$\quad$ ii)Female(\%) & 9 \\
Education (no of schooling of years) & 12 \\
Experience (years) & 6.28 \\
Family size (no) & 36.7 \\
Ethinicity & 58.9 \\
i)Brahmin/Chettri(\%) & 4.4 \\
ii)Janajati/Dalit(\%) & \\
iii)Others(\%) & 2.9 \\
Land holding size(katthas) & 31.64 \\
i)Upland & 13 \\
ii)Lowland & \\
iii)Pond Size &
\end{tabular}


Journal of Agriculture and Natural Resources (2018) 1(1): 21-31

ISSN: 2661-6270 (Print), ISSN: 2661-6289 (Online)

The mean age of the respondents in the study site was $41.54 \%$ of the respondents were male whereas $46 \%$ were female. The average number of schooling of years was 9 . The average experience of fish farming in the study site was 12 yrs. $36.7 \%$ of the respondents belong to Brahmin/ chhetri ethinicity. $58.9 \%$ of the respondents belong to janajati and dalit community whereas remaining others were $4.4 \%$. The average area of upland, lowland and pond size was $2.9,31.64$ and 13 kattha respectively (Table 1).

\section{Cost of fish production per ha of the pond area per year.}

Table 2 presents the cost of fish production per ha of pond area per year. The total cost (TC) of fish production per ha of the pond area per year was Rs. 743798. The total variable cost was Rs. 585724.58 which was about 79 percent of the total cost. Variable cost in the production of fish comprises cost for fingerlings, feed, labour, fertilizers and manure, limestone, fuel and energy and miscellaneous cost.

Table 2. Cost of fish production per ha of the pond per year

\begin{tabular}{lcc}
\hline Cost particulars & Cost (Rs.) & Frequency \\
\hline Variable cost items & & 25.00 \\
\hline Labor & 185946.10 & 28.28 \\
Feed & 210394.40 & 9.64 \\
Fingerlings & 71743.58 & 1.16 \\
limestone & 8614.88 & 4.75 \\
Manure and fertilizers & 35350.61 & 2.40 \\
Fuel and Energy & 17836.41 & 6.35 \\
Maintenance & 47234.76 & 1.10 \\
Miscellaneous & 8603.84 & 78.74 \\
\hline TVC & 585724.58 & 15.93 \\
\hline Fixed cost items & & 2.96 \\
\hline Land rent & 118496.80 & 2.37 \\
Interest & 22027.14 & 21.26 \\
Depreciation & 17549.68 & \\
\hline TFC & 158169.20 & \\
\hline Total cost & 743798.20 & \\
\hline
\end{tabular}

Of the total cost, feed cost is found to be the largest cost item. It incurs about 28 percent of the total cost. Feed cost is followed by the labour cost which is 25 percent of the total cost. The cost for the purchase of fingerlings was about 10 percent of the total cost. Cost for maintenance, manure cum fertilizers, fuel cum energy, limestone and others respectively occupy about 6, 5, 3, 1 and 1 percent of the total cost. The total fixed costs of fish production per ha of pond area is Rs. 158169.2 which is about 21 percent of the total cost. The major headings under fixed costs 
Journal of Agriculture and Natural Resources (2018) 1(1): 21-31

ISSN: 2661-6270 (Print), ISSN: 2661-6289 (Online)

are rental value of land, interest on long term loan and depreciation of tools which incur about 16, 3 and 2 percent of the total cost, respectively (Table 2).

\section{Cost and return per ha of pond area}

The total cost of fish production per ha of pond area in study area was found to be Rs. 743798 (Table 3). It varied in between Rs. 252562 to Rs. 2791600. The total return (TR) and net profit realized per ha were Rs. 1223934 and Rs. 480135, respectively. The maximum level of TR and net profit realized per ha were Rs. 3880000 and Rs. 1759140, respectively. The minimum TR per ha was found to be Rs. 131250. The result showed that some farms have attained negative profit. It means some farms were in loss and the maximum loss realized per ha was Rs. -496290 (Table 3).

Table 3. Minimum, maximum and average of cost, return and profit per ha of pond area in the study area

\begin{tabular}{llll}
\hline Description & Minimum (Rs.) & Maximum (Rs.) & Average (Rs.) \\
\hline Cost & 252562 & 2791600 & 743798.20 \\
Return & 131250 & 3880000 & 1223934.00 \\
Net profit/loss & -496290 & 1759140 & 480135.80 \\
\hline
\end{tabular}

Among three study sites, the cost of fish production per ha of pond area was highest for east Chitwan (Rs. 978652) followed by west Chitwan (Rs. 630382) and south Chitwan (Rs. 622360), respectively. Similarly, the TR and net profit realized per ha were highest for east Chitwan (Rs. 1700307 and Rs. 721654) followed by west Chitwan (Rs. 1087222 and Rs. 456839.2) and south Chitwan (Rs. 884272.3 and Rs. 261912.3), respectively (Table 4).In some areas of south Chitwan, especially in buffer area where farmers are supported by TAAL project for pond digging, the main purpose of pond digging was to prevent wildlife rather than fish farming. They used very less amount of inputs in the pond and similar was the fish harvest. Also, the commercial fish farmers of this study site used to harvest fish once a year while the farmers of east and west Chitwan harvest fish once in 8 months. Due to these reasons, the cost, return and profit were found to be lowest for south Chitwan as compared to east and west Chitwan.

Table 4. Cost, return and net profit of fish farming in different sites of the study area

\begin{tabular}{llll}
\hline Descriptions & East Chitwan & West Chitwan & South Chitwan \\
\hline Return & 1700307 & 1087222 & 884272 \\
Cost & 978652 & 630382 & 622360 \\
Profit & 721654 & 456839 & 261912 \\
\hline
\end{tabular}

\section{Benefit-cost ratio}

It gives an idea about recovery of cost incurred during production process by return obtained from sell of product. The $\mathrm{B} / \mathrm{C}$ ratio was found to be 1.63 for fish farming in Chitwan district. The 
Journal of Agriculture and Natural Resources (2018) 1(1): 21-31

ISSN: 2661-6270 (Print), ISSN: 2661-6289 (Online)

respondents were sampled randomly from three different part i.e. east, west and south Chitwan. Among them the $\mathrm{B} / \mathrm{C}$ ratio was found to be higher for east Chitwan i.e. 1.74 followed by west and south Chitwan i.e. 1.72 and 1.42 , respectively (Table 16 ). The $\mathrm{B} / \mathrm{C}$ ratio was found to be greater than unity. Thus, we can conclude that fish production in Chitwan district is profitable.

Table 5. B/C ratio of fish farming in the study area

\begin{tabular}{lc}
\hline Places & B/C ratio \\
\hline East Chitwan & 1.74 \\
West Chitwan & 1.72 \\
South Chitwan & 1.42 \\
\hline Average & 1.63 \\
\hline
\end{tabular}

\section{Production function analysis}

Lots of inputs are required for fish production. Each input has certain degree of effect on the quantity of fish produced or the quantity of fish produced is result of the effect of inputs used. For estimation of such effect of inputs, in this study, extended Cobb-Douglas production function was applied and the result obtained is expressed in Table 6.

Table 6. Estimated values of the coefficients and related statistics of Cobb-Douglas production function of Fish Production

\begin{tabular}{lccc}
\hline \multirow{2}{*}{ Factors } & \multicolumn{2}{c}{ Un-standardized Coefficients } & t- value \\
\cline { 2 - 3 } & Coefficients & Std. Error & 6.973 \\
\hline (Constant) & $6.413^{* * *}$ & 0.920 & 5.586 \\
Labour & $0.438^{* * *}$ & 0.078 & 1.267 \\
Feed & 0.043 & 0.034 & 4.441 \\
Fingerlings & $0.149^{* * *}$ & 0.034 & 3.721 \\
Fuel and energy & $0.038^{* * *}$ & 0.010 & 0.799 \\
Manure and fertilizers & -0.014 & 0.018 & \\
\hline
\end{tabular}

$\mathrm{R}=0.784, \mathrm{R}$ square $=0.615$, Adjusted $\mathrm{R}$ square $=0.592$, S.E. $=0.374, \mathrm{~F}$-value $=26.795$

$* * *, * *$ and $*$ represent significant at $1 \%, 5 \%$ and $10 \%$ level, respectively.

To determine the effect of variable inputs, Cobb-Douglas production function was used (Table 6). Five variables were estimated to show their effects on production of fish such as human labor cost, feed cost, fingerlings cost, manure and fertilizers cost and fuel cum energy cost. Out of the five variables three variables such as human labor cost, fingerlings cost, energy cost were significant at 1 percent level and other two variables such as feed cost and manure cum fertilizers cost were not significant. The sum of the coefficients of different inputs was calculated to be 0.654 for fish production. This indicates that the production function exhibited a decreasing return to scale and implies that 1 percent increment in all the inputs included in the function will increase income by 0.654 percent. 
Journal of Agriculture and Natural Resources (2018) 1(1): 21-31

ISSN: 2661-6270 (Print), ISSN: 2661-6289 (Online)

The coefficient of multiple determinations $\mathrm{R}^{2}$ of the model was 0.615 for fish production. It indicates that about 61.5 percent of variation in gross return was caused by the explanatory variables, which were included in the model. The value of adjusted $R$ square was 0.592 indicating that after taking into account the degree of freedom (df) 59.2 percent of the variation in the dependent variable was explained by the independent variables included in the model. The F-value was found to be 26.79 , which is highly significant (i.e. significant at $1 \%$ ) indicating that all the inputs included in the model were important for explaining the variation in total revenue of fish production in the study area.

\section{DISCUSSIONS}

The total cost of production was found to be Rs. 743798 and that of estimated by DOFD was Rs. 792740 (Byabasayik Matsya Palan Prabidhi, 2072). It implies that the production cost in the study area was in consistent with the cost estimated by DOFD.

Variable cost constituted about 79 percent of the total cost of production. Within the variable cost, feed cost was the largest cost item with 28 percent contribution to total cost of production. According to Oluwasola and Damilola, in Nigeria (2013) variable cost accounted for 78 percent of total cost of production. Similar result was found by Akinyele John (2011) in Nigeria in which variable cost accounted 74 percent of the total cost of production and feed cost accounted about 24.72 percent of the total cost of production. Similarly, Olasunkanmi, 2012 from Nigeria found that variable cost accounted for about 87 percent of the total cost of production and feed cost incur 34 percent of the total cost of production. This result is also in consistent with the result of the research done by Penda et al., 2013 in Benue state Nigeria. Awoyemi and Ajiboye (2011), also reported feed cost as the largest cost item with 17.7 percent contribution to total cost of production.

Among variable cost, labour cost $(25 \%)$ was second large cost item followed by fingerlings (10\%), maintenance cost (6\%), manure and fertilizers (5\%), fuel cum energy (3\%), limestone (1\%) and miscellaneous cost (1\%), respectively. The expense on fingerlings was 10 percent of the total cost. Similar result i.e. 12.4 percent of expenditure on fingerlings was found by Awoyemi and Ajiboye (2011) in Nigeria. Therefore, in the study farmers expend more on feed, labour and fingerlings.

Fish production in Chitwan district seems to be a profitable business as indicated by the $\mathrm{B} / \mathrm{C}$ ratio of 1.63. The B/C ratio calculated by Oluwasola and Damilola, in Nigeria (2013) was 1.5. Similarly B/C ratio calculated by Olaoye, 2013 in Nigeria was 1.69.The B/C ratio for fish production performed by Olasunkanmi in the Osun state of Nigeria was found to be 1.65.

The effect of labour, fingerlings and fuel cum energy on gross revenue was statistically significant at 1 percent. The sum of elasticity of variables included in the model was found to be 0.654 indicating diminishing returns in nature. Akinyele John, 2011 in Nigeria found similar kind of result in which the coefficient of production is 0.781 which implies that production 
Journal of Agriculture and Natural Resources (2018) 1(1): 21-31

ISSN: 2661-6270 (Print), ISSN: 2661-6289 (Online)

occurs in second stage of production function. This finding is also consistent with that of Olagunju et al. (2007) in their study on economic viability of cat fish production in Oyo state, Nigeria. The research done by Penda, et.al, also showed the decreasing returns of scale with sum of the coefficient of production to be 0.591 .

\section{CONCLUSION}

Being a country of sufficient water resources with diverse agro-climatic zones and species diversity, Nepal has great opportunity of growing different fish species from terai to hilly region. The study was conducted among 90 fish farmers who were randomly selected from three different sites i.e. east, west and south Chitwan, 30 from each study site.

With annual production cost of Rs.743798, the total return and net profit realized per ha per year were Rs. 1223934 and Rs. 480135, respectively. Out of total cost, about 79.00 percent was variable cost and remaining 21.00 percent was fixed cost. Feed cost, largest cost component, accounted for about 28.00 percent followed by cost for labour, fingerlings, maintenance, manure cum fertilizers, fuel cum energy, limestone and others, respectively occupying 25.00, 10.00, $6.00,5.00,3.00,2.00$ of the total cost. The fixed cost components i.e. rental value of land, interest on long term loan and depreciation of fixed assets occupied about 16.00, 3.00 and 2.00 percent respectively of the total cost.

The cost of fish production per ha of pond area of the study area was found to be Rs. 743798 . Differences in Cost, return and profit has been found in different sites. The production cost has been found to be highest for east Chitwan (Rs. 978652.1) followed by west Chitwan and south Chitwan of Rs. 630382.6 and Rs. 622360, respectively. Total return for east, west and south Chitwan was found to be Rs. 1700307, Rs. 1087222 and Rs. 884272, respectively. Despite the higher production cost, the return and profit were found to be higher for east Chitwan. Similarly, the $\mathrm{B} / \mathrm{C}$ ratio was found to be greater i.e. 1.74 for east Chitwan followed by west (1.72) and south Chitwan (1.42). Fish enterprise was found to be profitable in the study area as indicated by the $\mathrm{B} / \mathrm{C}$ ratio of 1.63 .

The return to scale was found to be 0.654 i.e. decreasing return to scale. Among five variable considered, three variables such as human labor cost, fingerlings cost, energy cost were significant at 1 percent level and other two variables such as feed cost and manure and fertilizers cost were insignificant even at 10 percent level of significance. 
Journal of Agriculture and Natural Resources (2018) 1(1): 21-31

ISSN: 2661-6270 (Print), ISSN: 2661-6289 (Online)

\section{ACKNOWLEDGEMENTS}

The research was supported financially by department of research and extension (DOREX), AFU. I want to acknowledge all the respondents who had supported this study by providing their valuable information and precious time. At last I 'am grateful to all those supporting hands who helped me either directly or indirectly for completing this study

\section{Author Contributions}

T.S designed and performed experiments, analysed data and wrote the paper; S.C.D, R.R.K and K.G . developed the methodology;. and T.S wrote the manuscript in consultation with J.L. J.L revise the article for the final approval of the version to be published.

\section{Conflicts of Interest}

The authors declare that there is no conflicts of interest regarding the publication of this paper.

\section{REFERENCES}

Akinyle, J. (2011). Analysis of Profitability of Fish Farming in Osun State, Nigeria. Journal of Economics and Sustainable development, $\mathrm{Vol}(2), 1-8$.

Annual report. (2013). Directorate of Fisheries Development (DoFD), Central Fisheries 'Building, Balaju, Kathmandu, Nepal.

Awoyemi, T. T., \& Ajiboye, A. J. (2011). Analysis of profitability of fish farming among women in Osun state, Nigeria. 2 (4).

Karki, N. P. (2016). Fish farming in Nepal : trends, opportunities and constraints. Nepalese journal of agricultural sciences , 201-210.

Olagunju, F., Adesiyan, I., \& Ezekiel, A. (2007). Economic viability of cat fish production in Oyo state Nigeria. Journal of human ecology, 21 (2), 121-124.

Olaoye, O., Ashley, S. D., Fakoya, E., Ikeweinwe, N., Alegbeleye, W., Ashaolu, F., et al. (2013). Assessment of socio-Economic analysis of fish farming in Oyo state,

Olasunkanmi, J. B. (2012). Economic analysis of fish farming in Osun state, South-Western Nigeria. IIFET 2012 Tanzania Proceedings.

Oluwemimo, O., \& Damilola, A. (2013). Socio-economic and policy issues determining sustainable fish farming In Nigeria. International journal of livestock production, 4 (1), $1-8$.

Penda, S. T., Umeh, J. C., \& Unaji, G. P. (2013). Resource use efficiency among fish farmers using earthen pond system in Benue state, Nigeria. International journal of research in social sciences, 3 (1). 
Journal of Agriculture and Natural Resources (2018) 1(1): 21-31

ISSN: 2661-6270 (Print), ISSN: 2661-6289 (Online)

Rai, A. K., Clausen, J., \& Simon, S. F. (2008). Potential development interventions for fisheries and aquaculture in Nepal. Food and agriculture organization of the united nations regional office for Asia and the pacific. Bangkok: APFIC AD HOC PUBLICATION. 